\title{
AC 2012-4380: ANALYSIS OF FIRST-YEAR ENGINEERING STUDENT ESSAYS ON ENGINEERING INTERESTS FOR INSTITUTIONS OF DIF- FERENT CARNEGIE CLASSIFICATIONS
}

\section{Dr. Benjamin Emery Mertz, Arizona State University}

Benjamin Mertz is currently a lecturer at Arizona State University, where he is a part of a team in charge of developing and improving the first-year engineering classes. Besides the Introduction to Engineering class, he also teaches aerospace and mechanical engineering classes at ASU. He received his Ph.D. in aerospace engineering from the University of Notre Dame in 2010 and his B.S. in mechanical engineering from Rose-Hulman Institute of Technology in 2005.

Dr. Sara A. Atwood, Elizabethtown College

(C)American Society for Engineering Education, 2012 


\title{
Analysis of First-Year Engineering Student Essays on Engineering Interests for Institutions of Different Carnegie Classifications
}

\begin{abstract}
:
At the 2011 ASEE meeting, a study was presented investigating the factors that motivate students' initial pathway into engineering. Results showed that while common themes emerged, there were differences in motivation between genders and amongst disciplines. As a follow-up to this study, we investigated responses of freshman engineering students to the same question at two new institutions: a large state research university and a small regional liberal arts college. We hypothesized that incoming students at these different types of institutions would be interested in engineering for different reasons.
\end{abstract}

As part of an in-class assignment for the Introduction to Engineering courses at each institution, students were asked to respond to the prompt, "Engineering is a very broad field of study. What is it about engineering that interests you?" The essay responses of 215 students (49 from the small liberal arts college and 166 from the large state university) were reviewed by two engineering education researchers (initially coded independently and then codes compared for final classification). The coding used in the 2010 study was followed for this study. Response frequencies for the different coding categories were compared for the two present institutions as well as the original mediumsized private selective research (or comprehensive) university.

The top reasons that students cited were similar at all three institutions. They included: innovation/creativity/design, building things, math/science, practicality/real world applications, knowing how things work, and problem solving. The least popular reasons were also similar for all three institutions: preparation for another career, group work, a family member in engineering, previous experience in engineering, and engineering being a broad field.

Statistically significant differences in responses were found amongst the different types of institutions. Two of the overall most popular responses, math/science and problem solving, were significantly more popular at the medium private selective research university and significantly less popular at the large state research university. Conversely, another overall most popular response, innovation/creativity/design was significantly more popular at the large state research university and significantly less popular at the medium private research university. Amongst the least popular responses at all institutions, students at the large state research university had statistically fewer responses than the overall mean in the categories of engineering being a good career, a broad field, having previous experience, and having a family member in engineering. Conversely, the medium private research university had more respondents in the categories of having previous experience, a family member in engineering, and engineering being a broad field. Specific Career and Preparation for Other Career were cited significantly less frequently at the small private liberal arts college than the mean and other comparisons are limited based on the small sample size at this institution. 
With regard to gender, statistically significant differences were seen at both institutions (large and medium sized), although in different categories. At the large state research institution math/science and specific interests were cited more frequently by females and broad field was cited more frequently by males. At the medium private research university build things, how things work, design/creative/innovative were cited more frequently by males, while better world was cited more frequently by females.

\section{Introduction:}

The decline in student interest in STEM fields and the rising demand for well-trained scientists and engineershas been noted in several National Reports as an issue of concern if the U.S. is to remain competitive in a global market ${ }^{2,6,11}$. This has prompted many education researchers to study the motivations of students to pursue an engineering degree.

Some motivating factorswere found to be cited more frequently by those who did not persist in STEM fields, such as influence from family members to pursue engineering ${ }^{7}$. Seymour and Hewitt found that this was especially true for women ${ }^{15}$. Having a parent who is an engineer ${ }^{1}$ and the influences of parents and teachers have also been reported as being important factors for students choosing to study engineering in college ${ }^{5}$.Initial motivations such as the influence of others, material/pragmatic considerations, an appropriate next step since they are good at math and science, or initially choosing their major with little understanding of what their major would involve were common for those who did not persist ${ }^{15}$.

Different motivations between genders have also been noted. For instance, financial compensation was found to be of greater significance for males choosing engineering, while genuine interest in the field was especially critical for females ${ }^{5,15}$. Males also tended to emphasize the "hands-on" aspects of engineering or interest/proficiency in building things as reasons for pursuing engineering more often than females ${ }^{10}$. Males were found to cite "good at math and science in high school" nearly twice as often as females ${ }^{15}$. Altruistic purposes for studying engineering have been found to be important motivating factors for many students, but more so for females ${ }^{4,8,10}$.

Seymour and Hewitt's seminal work in engineering student motivations has greatly influenced the engineering education community's understanding of the reasons students persist in engineering. Their extensive interviews of students who persisted in engineering, as well as those who switched out, revealed the student's desire to feel passionate about what they do, feel a social purpose, and maintain a healthy work-life balance in their future career ${ }^{15}$.

At the 2011 ASEE Conference, a paper by Meyers and Mertz sought to understand what, if any, initial motivational factors could be correlated to persistence (or non-persistence) in engineering nearly 10 years after Seymour and Hewitt's work. While no definitive conclusions could be drawn, many of the results from the studies mentioned earlier were also observed in this study. These observations included motivational differences 
between genders: females were found to cite altruistic purposes for studying engineering more frequently than males, and males were found to mention building things and knowing how things work more often than females. Quotations from the student responses were used alongside the response frequency data to suggest that a better understanding of what engineering entails before entering an engineering program in college may aid in the recruitment and retention of students ${ }^{10}$.

One of the limitations mentioned in the work of Meyers and Mertz was that it represented responses of students from a single institution, and thus the ability to generalize these results was yet to be determined. Institutional effects have had varying significance in relevant studies found in literature. Besterfield-Sacre, et al. studied attitude differences between genders and ethnicities of freshman before and after their first year of study at 17 institutions. The pre-test results were mostly consistent across institutions. However, the directional changes between the pre and post-tests did show institutional

dependency $^{3}$. This suggests similarities between student attitudes entering the programs but that institutional differences can cause different changes in those attitudes. Other researchers have found that the "selectivity" of the institutions (as measured by the average GPA and/or standardized test scores of incoming students) does affect the graduation rate of engineers between institutions ${ }^{12,14,16}$.

The present work seeks to better understand the institutional similarities and differences in student motivations to pursue engineering degrees and address the limitations of the work of Meyers and Mertz. This study is a unique follow-up to the study of Meyers and Mertz. Data from the medium private research university studied in that initial paper was used, and two additional institutions were added: a large public research university and a small private regional liberal arts college. It is expected that the significant differences in size and Carnegie classifications between institutions should accentuate any differences between student responses at the different institutions. The prompt from the previous study was used to elicit responses from freshman students entering engineering programs in the Fall of 2011 at the two new institutions. While it is too early to link the responses from the present study to persistence (or non-persistence), the frequency of responses was compared between institutions. The data was also analyzed with respect to gender for the large and medium-sized schools (the female population at the small school was too small to be used in this analysis).

\section{Methods:}

Data for this study were taken from student essays written as part of an in-class assignment. As a part of this assignment, the students were asked to respond to the prompt, "Engineering is a very broad field of study. What is it about engineering that interests you?" Two engineering education researchers reviewed and coded these qualitative reflections independently. The independently coded responses were compared and discussed until a consensus was formed. The coding categories and definitions were taken from Meyers and Mertz ${ }^{10}$. Tabulations, frequencies, and simple statistical breakdowns, combined with excerpts from student responses, are used in this paper to help tell the story of the commonalities and distinctions represented by the students at 
each school. Using both quantitative and qualitative methods in conjunction strengthened and supported the findings through triangulation ${ }^{9,13}$. The findings at each school were then compared in order to discern the commonalities and differences between students' interests in engineering at different institutions.

All of the students represented in this study were enrolled in a similar first-year Introduction to Engineering course at their respective institutions and were required to complete the same in-class assignment. Informed consent was obtained from all participants in the study and all coding was done with an anonymous identifier. Internal Review Board approval of all research protocols was obtained at each institution.

\section{Setting and Population}

The administration site for the original study was a medium sized (undergraduate student population of $\sim 8,000$ students), Midwestern, private, relatively selective institution with a traditional student composition (the vast majority of students complete their undergraduate studies in four years and are in the age range of 18-22). The course ("Introduction to Engineering") in which the assignment was administered is a part of a separate First-Year Studies program. Students do not actually select majors (whether engineering or something else) until near the end of their first-year when they register for classes for the upcoming fall semester. With only a few exceptions, any student considering an academic pathway within engineering takes the two-semester course sequence "Introduction to Engineering" in which the assignment was administered. The assignment was administered early in the fall semester of 2007. The 163 essays from this institution represent students from all of the disciplines of engineering offered (Aerospace and Mechanical Engineering 27\%, Chemical and Biomolecular Engineering $18 \%$, Civil Engineering and Geological Sciences 11\%, Computer Science and Engineering 6\%, and Electrical Engineering 8\%), and is 31\% female and 69\% male which is roughly representative of the gender distribution at the institution studied.

The second administration site was a large (undergraduate student population of $>50,000$ students) Southwestern public research institution. While the majority of the student population can be considered traditional (as defined above), there is a slightly larger nontraditional student population than at the other institutions. At this institution, the students are admitted directly into their chosen discipline upon admission to the university. The "Introduction to Engineering" course varies somewhat between the different engineering disciplines; however, the version of the course where this assignment was administered consisted of Mechanical, Electrical, and Aerospace Engineering majors. It is a required course for degrees in these disciplines. Of the 15 sections (each consisting of $\sim 40$ students) of the course, 9 participated in this study. The included/excluded sections were determined completely by the various instructors' willingness to participate in the data collection process. The demographics of the students in these sections are representative of the engineering student body within the Mechanical, Electrical, and Aerospace Engineering departments. The prompt was given as part of an in-class assignment on the first day of class during the fall semester of 2011. As stated above, the 166 essays from this institution represent students of only the 3 
disciplines mentioned earlier (Mechanical Engineering 44\%, Aerospace Engineering $30 \%$, and Electrical Engineering 26\%), and is 86\% male and $14 \%$ female.

The third administration site was a small (undergraduate student population of $<2,000$ students) Eastern regional private liberal arts college with a traditional student population. The "Introduction to Engineering" course at this school is required of all engineering majors in a general engineering curriculum with concentrations in mechanical, electrical, and computer engineering. All students enrolled in this course during the fall semester of 2011 were administered the prompt on the first day of class. The 49 essays represent all of the disciplines mentioned earlier; however, since it is a general engineering program it is difficult to distinguish disciplines within this data set. The class was only $6 \%$ female and so comparisons of responses related to gender cannot be performed for this institution. Also, three of the responses were from sophomores who were switching to the engineering major.

\section{Coding}

The 14 different coding categories from Meyers and Mertz ${ }^{10}$ were adopted for this study.The categories used were "Math/Science," "Better World," "Problem Solving," "Build Things," "Practicality," "Specific Interests," "Prepare for Other Career," "Family," "Broad," "Groups", "Innovative/Creative," "Previous Experience," "Good Career," and "How things Work." A description of the different coding categories along with example statements which would fall into each category are shown in Table 1 . The students' responses were grouped into these categories and then tallied. These categories were found to encompass all of the student responses found in the present study.

Table 1: Coding for Student Motivation Essays

\begin{tabular}{|l|l|l|}
\hline \multicolumn{1}{|c|}{ Category } & \multicolumn{1}{|c|}{ Description } & \multicolumn{1}{c|}{ Example Statements } \\
\hline Math/Science & $\begin{array}{l}\text { Indicate aptitude or enjoyment of a math or } \\
\text { science class (also includes comments about } \\
\text { specific math/science class) }\end{array}$ & $\begin{array}{l}\text { "I have always liked math and } \\
\text { science classes" or "My best } \\
\text { classes were my math and } \\
\text { science classes" }\end{array}$ \\
\hline Better World & $\begin{array}{l}\text { Wishes to study engineering for an altruistic } \\
\text { purpose }\end{array}$ & $\begin{array}{l}\text { "I want to make other } \\
\text { people's lives easier or better" } \\
\text { or "I want to make a mark on } \\
\text { the world." }\end{array}$ \\
\hline Problem Solving & Enjoy solving problems & $\begin{array}{l}\text { "I have always enjoyed } \\
\text { solving problems" or "I like } \\
\text { solving puzzles" }\end{array}$ \\
\hline Build Things & $\begin{array}{l}\text { Indicate enjoyment in creating something } \\
\text { new from nothing or fix broken things (we } \\
\text { also included coding or computer program } \\
\text { development in this category) }\end{array}$ & $\begin{array}{l}\text { "I've always liked to build } \\
\text { things" or "I enjoy } \\
\text { constructing something } \\
\text { useful." }\end{array}$ \\
\hline Practicality & $\begin{array}{l}\text { Indicate desire to apply skills to real world } \\
\text { applications }\end{array}$ & $\begin{array}{l}\text { "I enjoy applying math and } \\
\text { science to real world } \\
\text { problems" }\end{array}$ \\
\hline $\begin{array}{l}\text { Specific } \\
\text { Interests }\end{array}$ & $\begin{array}{l}\text { Indicate a desire to study a particular } \\
\text { discipline of engineering (only for those }\end{array}$ & $\begin{array}{l}\text { "I have always wanted to } \\
\text { study Aerospace }\end{array}$ \\
\hline
\end{tabular}




\begin{tabular}{|l|l|l|}
\hline & $\begin{array}{l}\text { responses that indicate certainty of specific } \\
\text { type of engineering) }\end{array}$ & $\begin{array}{l}\text { Engineering" or "I want to } \\
\text { build skyscrapers (Civil } \\
\text { Eng.)" }\end{array}$ \\
\hline $\begin{array}{l}\text { Prepare for } \\
\text { Other Career }\end{array}$ & $\begin{array}{l}\text { Studying engineering in preparation for } \\
\text { another field upon graduation }\end{array}$ & $\begin{array}{l}\text { "Engineering will prepare me } \\
\text { to be a patent lawyer" or "I } \\
\text { plan to go into the air force" }\end{array}$ \\
\hline Family & $\begin{array}{l}\text { Immediate or extended family member is an } \\
\text { engineer or in a closely related field }\end{array}$ & $\begin{array}{l}\text { "My father is an electrical } \\
\text { engineer" }\end{array}$ \\
\hline Broad & Wide range of career paths available & $\begin{array}{l}\text { "I can do all kinds of things } \\
\text { with an engineering degree" }\end{array}$ \\
\hline Groups & $\begin{array}{l}\text { Desire to work in groups or collaborate with } \\
\text { other people (engineers or not) }\end{array}$ & $\begin{array}{l}\text { "I enjoy working with other } \\
\text { people" or "I like being a part } \\
\text { of a team" }\end{array}$ \\
\hline $\begin{array}{l}\text { Innovative/ } \\
\text { Creative/Design }\end{array}$ & $\begin{array}{l}\text { Desire to design, create, or study new things } \\
\text { "I want to be on the cutting } \\
\text { edge of technology" or "I } \\
\text { enjoy designing new things" }\end{array}$ \\
\hline $\begin{array}{l}\text { Previous } \\
\text { Experience }\end{array}$ & $\begin{array}{l}\text { Have had an experience with engineering } \\
\text { through a class, extracurricular activity, } \\
\text { mentoring relationship, or internship }\end{array}$ & $\begin{array}{l}\text { "I was a part of my high } \\
\text { school's Lego robotics team" } \\
\text { or "I spent a summer working } \\
\text { as an intern" }\end{array}$ \\
\hline $\begin{array}{l}\text { Good Career } \\
\text { How Things } \\
\text { Work }\end{array}$ & $\begin{array}{l}\text { Studying engineering because of career } \\
\text { opportunities } \\
\text { money" or "engineering is a } \\
\text { rewarding career" }\end{array}$ \\
\hline
\end{tabular}

\section{Statistical Analysis}

Since more than two groups were being compared, ANOVA principles were used for statistical comparison. An overall mean was calculated by putting all of the students' responses together into one large group of 378 students. Each individual institution's mean was then compared to that overall group mean using a two-tailed t-test assuming unequal sample sizes and unequal variance. Adjustments for multiple comparisons to control the overall error rate were not performed because the researchers were more concerned with increasing the power to detect trends, and because only three groups were compared.

\section{Results}

Overall, math/science, innovation/creativity/design, problem solving, making a better world, and building things were the most popular responses of first-year engineering majors to the question of why they were interested in engineering. The least popular responses were engineering being a good career, a broad field of study, having previous 
experience in engineering, a family member in engineering, enjoying group work, or using engineering as preparation for another career (Table 2).

These results were relatively consistent amongst the institutions. In the top five responses at each institution, there were eight distinct categories: innovation/creativity/design (all three), building things (two), math/science (two), practicality/real world applications (two), how things work (two), problem solving (two), and specific interest (one) and better world (one).

In the least frequent five responses at each institution, only six distinct categories were cited: preparation for another career (all three), group work (all three), a family member in engineering (all three), previous experience in engineering (all three), a broad field (two), and a good career (one).

Table 2: Responses in order of most frequently occurring to least frequently occurring.

\begin{tabular}{|c|c|c|c|}
\hline Overall & $\begin{array}{c}\text { Medium Private } \\
\text { Research University }\end{array}$ & $\begin{array}{c}\text { Large State } \\
\text { Research University }\end{array}$ & $\begin{array}{c}\text { Small Private } \\
\text { Regional Liberal } \\
\text { Arts College }\end{array}$ \\
\hline Math/Science & Math/Science & $\begin{array}{c}\text { Innovative/ } \\
\text { Create/Design }\end{array}$ & Math/Science \\
\hline $\begin{array}{l}\text { Innovative/ } \\
\text { Create/Design }\end{array}$ & Problem Solving & How Things Work & $\begin{array}{c}\text { Innovative/ } \\
\text { Create/Design }\end{array}$ \\
\hline Problem Solving & Better World & Build Things & Build Things \\
\hline Better World & $\begin{array}{c}\text { Innovative/ } \\
\text { Create/Design }\end{array}$ & Specific Interest & $\begin{array}{l}\text { Practicality/ } \\
\text { Real World }\end{array}$ \\
\hline Build Things & $\begin{array}{l}\text { Practicality/ } \\
\text { Real World }\end{array}$ & Problem Solving & How Things Work \\
\hline Specific Interest & Build Things & Better World & Problem Solving \\
\hline How Things Work & Specific Interest & Math/Science & Specific Interest \\
\hline $\begin{array}{l}\text { Practicality/ } \\
\text { Real World }\end{array}$ & Broad & $\begin{array}{l}\text { Practicality/ } \\
\text { Real World }\end{array}$ & Better World \\
\hline Good Career & How Things Work & Good Career & Good Career \\
\hline Broad & Previous Experience & Group Work & Broad \\
\hline Previous Experience & Family & Broad & Family \\
\hline Family & Good Career & Previous Experience & Previous Experience \\
\hline Group Work & Prep Other Career & Family & Group Work \\
\hline Prep for Other Career & Group Work & Prep Other Career & Prep Other Career \\
\hline
\end{tabular}


Statistically significant differences in response frequencies were found amongst the different types of institutions (Table 3, Figures 1 and 2).

At the medium private research university, a statistically larger number of students reported math/science, problem solving, making the world better, previous experience with engineering, engineering being a broad field, and having a family member in engineering as reasons they were interested in engineering. The only reason reported statistically less frequently than the entire sample mean by students was innovation/creativity/design.

At the large, public, research university, a statistically larger number of students reported innovation/creativity/design as a reason they were interested in engineering. A statistically smaller number of students reported math/science, problem solving, practicality, good career, broad application, previous experience, and family members in engineering.

The small, private, regional liberal arts college had fewer statistically significant differences due partially to the smaller sample size. There were a smaller number of students from the small, liberal arts college that reported making the world better, having a specific interest, and using engineering as preparation for another career as reasons for studying engineering.

Comprehensive data, including the frequency of responses along with a $95 \%$ confidence interval on that frequency and the p-value from the t-test compared to the overall frequency, are shown in Table 5 in the appendix.

With respect to gender, statistically significant results were found in the overall data in 9 of the 14 categories with building things, knowing how things work, and innovative/creative/design being cited more frequently by males and better world, math/science, problem solving, specific interests, previous experience, and broad being cited more frequently by females (Table 4, Figure 3 ).

Fewer significantly different results between genders were observed at the individual institutions and, in general, they were consistent with the overall (cross-institutional) results with one exception: the broad category was cited more frequently by males at the large public research institution, while overall, it was cited more frequently by females. 
Table 3: Frequencies of responses at each institution and statistical comparisons.

\begin{tabular}{|c|c|c|c|c|}
\hline & Overall & $\begin{array}{c}\text { Medium Private } \\
\text { Research } \\
\text { University }\end{array}$ & $\begin{array}{c}\text { Large State } \\
\text { Research } \\
\text { University }\end{array}$ & $\begin{array}{c}\text { Small Private } \\
\text { Regional } \\
\text { Liberal Arts } \\
\text { College }\end{array}$ \\
\hline Math/Science & 0.407 & $\begin{array}{c}0.613^{* *} \\
\uparrow\end{array}$ & $\begin{array}{c}0.169^{* * *} \\
\downarrow\end{array}$ & 0.531 \\
\hline $\begin{array}{l}\text { Innovative/ } \\
\text { Create/Design }\end{array}$ & 0.370 & $\begin{array}{c}0.258^{* *} \\
\downarrow\end{array}$ & $\begin{array}{c}0.482^{* * *} \\
\uparrow\end{array}$ & 0.367 \\
\hline $\begin{array}{l}\text { Problem } \\
\text { Solving }\end{array}$ & 0.275 & $\begin{array}{c}0.368^{* *} \\
\uparrow\end{array}$ & $\begin{array}{c}0.205^{*} \\
\downarrow\end{array}$ & 0.204 \\
\hline Better World & 0.243 & $\begin{array}{c}0.325^{*} \\
\uparrow\end{array}$ & 0.205 & $\begin{array}{c}0.102^{* *} \\
\downarrow\end{array}$ \\
\hline Build Things & 0.243 & 0.233 & 0.229 & 0.327 \\
\hline $\begin{array}{l}\text { Specific } \\
\text { Interest }\end{array}$ & 0.212 & 0.233 & 0.217 & $\begin{array}{c}0.122^{*} \\
\downarrow\end{array}$ \\
\hline $\begin{array}{l}\text { How Things } \\
\text { Work }\end{array}$ & 0.204 & 0.153 & 0.247 & 0.224 \\
\hline $\begin{array}{l}\text { Practicality/ } \\
\text { Real World }\end{array}$ & 0.193 & 0.239 & $\begin{array}{c}0.133^{*} \\
\downarrow\end{array}$ & 0.245 \\
\hline Good Career & 0.093 & 0.135 & $\begin{array}{c}0.048^{* * *} \\
\downarrow\end{array}$ & 0.102 \\
\hline Broad & 0.085 & $\begin{array}{c}0.160^{* *} \\
\uparrow\end{array}$ & $\begin{array}{c}0.018^{* * *} \\
\downarrow\end{array}$ & 0.061 \\
\hline $\begin{array}{l}\text { Previous } \\
\text { Experience }\end{array}$ & 0.079 & $\begin{array}{c}0.153^{* *} \\
\uparrow\end{array}$ & $\begin{array}{c}0.018^{* * *} \\
\downarrow\end{array}$ & 0.041 \\
\hline Family & 0.074 & $\begin{array}{c}0.141^{* *} \\
\uparrow\end{array}$ & $\begin{array}{c}0.012^{* * *} \\
\downarrow\end{array}$ & 0.061 \\
\hline Group Work & 0.032 & 0.025 & 0.042 & 0.020 \\
\hline $\begin{array}{l}\text { Prep for Other } \\
\text { Career }\end{array}$ & 0.026 & 0.049 & 0.012 & $\begin{array}{c}0.000^{* * *} \\
\downarrow\end{array}$ \\
\hline
\end{tabular}

* Significant with p-value less than 0.100

** Significant with p-value less than 0.050 


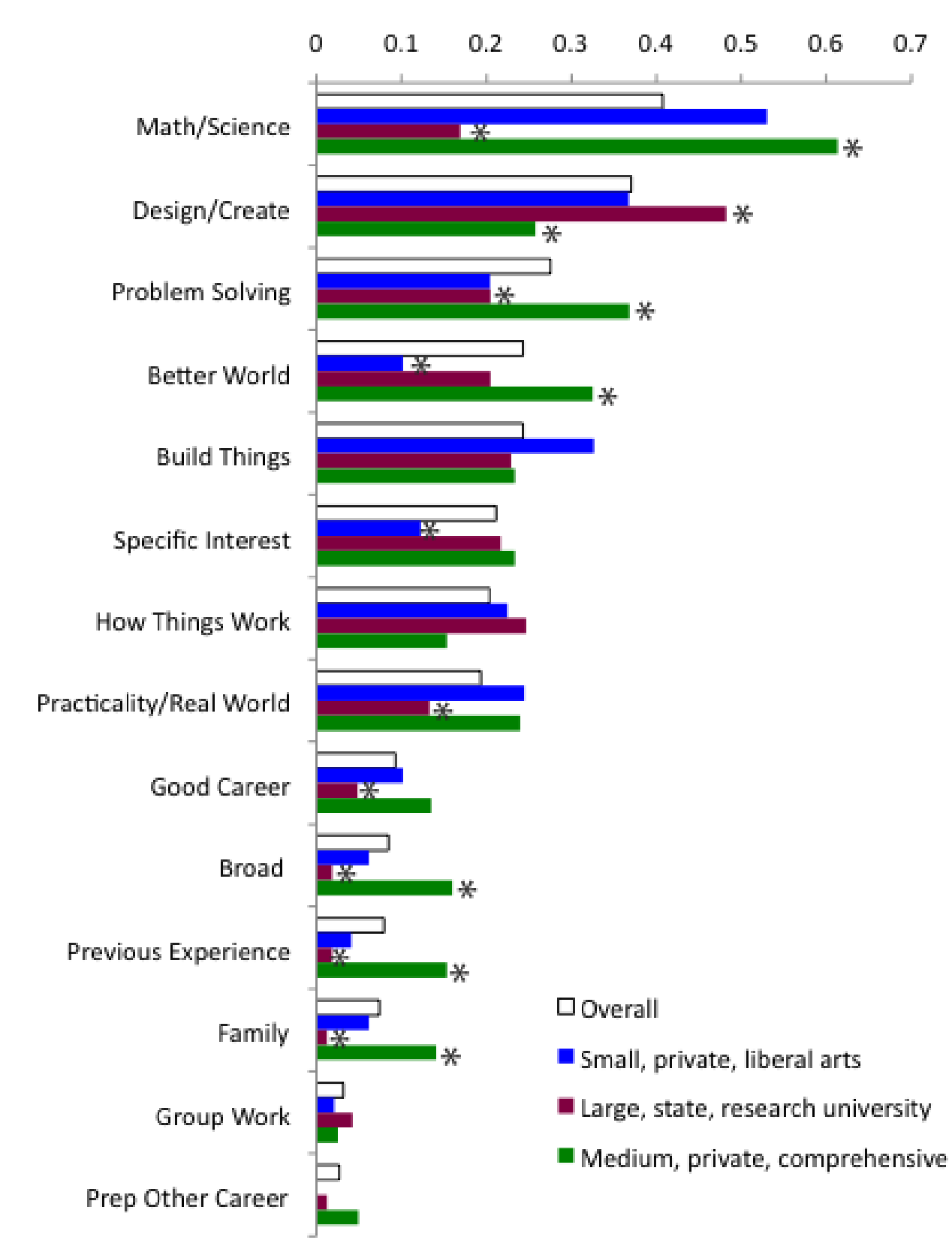

Figure 1: Responses from each institution listed in decreasing order of frequency. Statistically significant differences from the overall frequency are designated with an asterisk. 


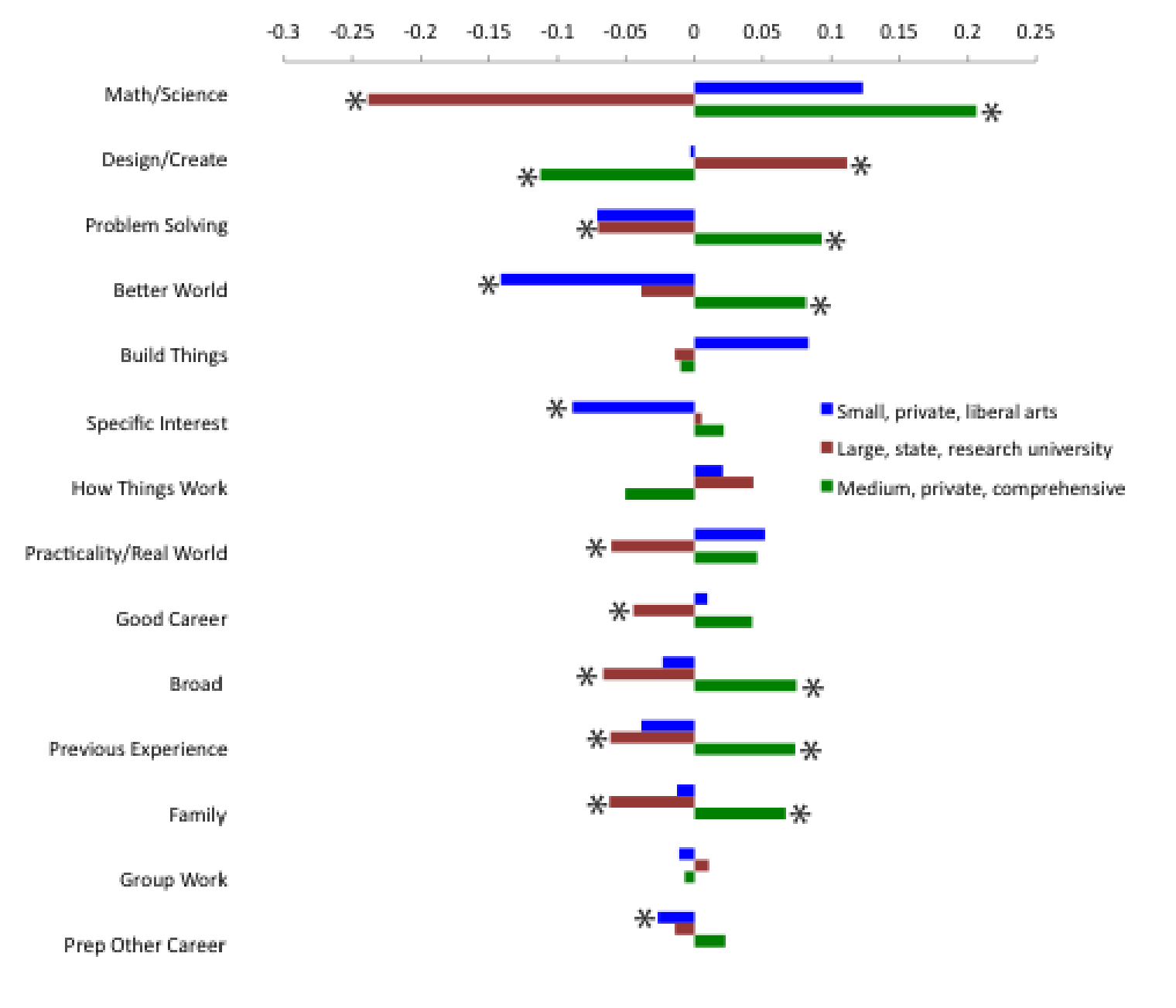

Figure 2: Difference from the overall mean, showing if an institution fell substantially above or below the overall mean for that category of response. Statistically significant differences from the overall frequency are designated with an asterisk. 
Table 4: Frequencies of responses at medium and large universities broken down by gender and statistical comparisons (bold values indicate statistically significant results).

\begin{tabular}{|l|c|c|c|c|c|c|c|r|r|}
\hline & \multicolumn{4}{|c|}{ Overall } & \multicolumn{2}{c|}{$\begin{array}{c}\text { Medium Private Research } \\
\text { University }\end{array}$} & \multicolumn{3}{c|}{$\begin{array}{l}\text { Large State Research } \\
\text { University }\end{array}$} \\
\hline & p-value & female & male & p-value & female & male & p-value & female & male \\
\hline Build Things & $\mathbf{0 . 0 0 0 1}$ & 0.105 & 0.278 & $\mathbf{0 . 0 0 0 2}$ & 0.078 & 0.304 & 0.4753 & 0.174 & 0.238 \\
\hline $\begin{array}{l}\text { How Things } \\
\text { Work }\end{array}$ & $\mathbf{0 . 0 0 0 9}$ & 0.092 & 0.232 & $\mathbf{0 . 0 0 0 6}$ & 0.039 & 0.205 & 0.7207 & 0.217 & 0.252 \\
\hline Better World & $\mathbf{0 . 0 0 1 1}$ & 0.408 & 0.202 & $\mathbf{0 . 0 0 4 3}$ & 0.490 & 0.250 & 0.8779 & 0.217 & 0.203 \\
\hline $\begin{array}{l}\text { Math/ } \\
\text { Science }\end{array}$ & $\mathbf{0 . 0 0 2 3}$ & 0.566 & 0.368 & 0.1919 & 0.686 & 0.580 & $\mathbf{0 . 0 5 9 8}$ & 0.348 & 0.140 \\
\hline $\begin{array}{l}\text { Problem } \\
\text { Solving }\end{array}$ & $\mathbf{0 . 0 0 8 4}$ & 0.408 & 0.242 & 0.1512 & 0.451 & 0.330 & 0.1311 & 0.348 & 0.182 \\
\hline $\begin{array}{l}\text { Innovative/ } \\
\text { Creative/Design }\end{array}$ & $\mathbf{0 . 0 2 2 6}$ & 0.263 & 0.397 & $\mathbf{0 . 0 3 1 6}$ & 0.157 & 0.304 & 0.9706 & 0.478 & 0.483 \\
\hline Specific Interest & $\mathbf{0 . 0 2 7 2}$ & 0.316 & 0.185 & 0.4189 & 0.275 & 0.214 & $\mathbf{0 . 0 7 4 6}$ & 0.391 & 0.189 \\
\hline $\begin{array}{l}\text { Previous } \\
\text { Experience }\end{array}$ & $\mathbf{0 . 0 6 0 0}$ & 0.145 & 0.063 & 0.3402 & 0.196 & 0.134 & 0.5145 & 0.043 & 0.014 \\
\hline Broad & $\mathbf{0 . 0 8 4 9}$ & 0.145 & 0.070 & 0.2227 & 0.216 & 0.134 & $\mathbf{0 . 0 8 3 3}$ & 0.000 & 0.021 \\
\hline Family & 0.1668 & 0.118 & 0.063 & 0.4117 & 0.176 & 0.125 & 0.1580 & 0.000 & 0.014 \\
\hline Good Career & 0.3172 & 0.066 & 0.099 & 0.1131 & 0.078 & 0.161 & 0.9083 & 0.043 & 0.049 \\
\hline $\begin{array}{l}\text { Practicality/ } \\
\text { Real World }\end{array}$ & 0.3605 & 0.158 & 0.202 & 0.3704 & 0.196 & 0.259 & 0.4337 & 0.087 & 0.140 \\
\hline $\begin{array}{l}\text { Prep Other } \\
\text { Career }\end{array}$ & 0.5005 & 0.039 & 0.023 & 0.7144 & 0.059 & 0.045 & 0.1580 & 0.000 & 0.014 \\
\hline Group Work & 0.6941 & 0.039 & 0.030 & 0.4816 & 0.039 & 0.018 & 0.9742 & 0.043 & 0.042 \\
\hline
\end{tabular}




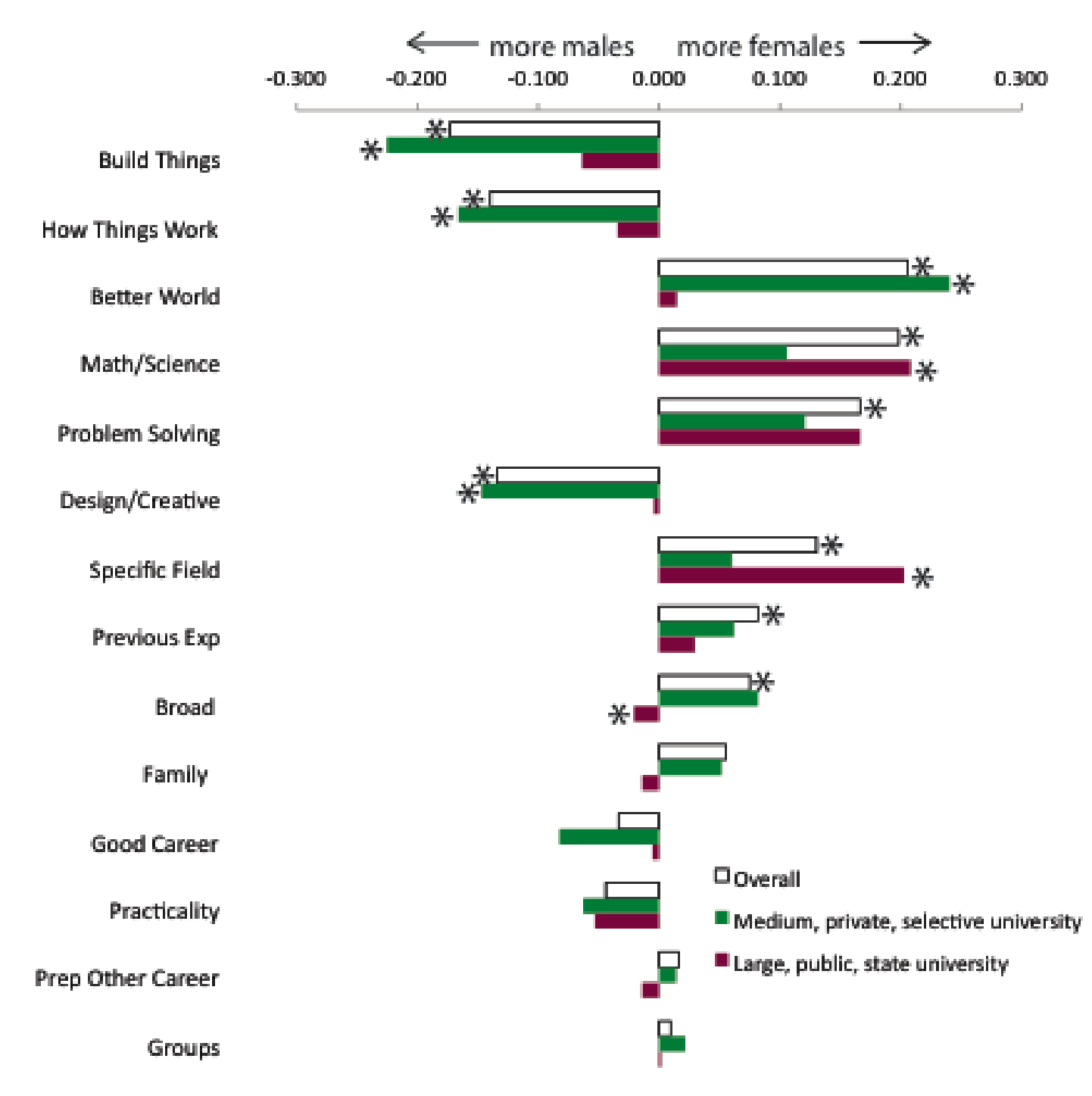

Figure 3: Differences in frequency of responses between male and female students, arranged in order of decreasing difference. Statistically significant differences from the overall frequency are designated with an asterisk.

\section{Discussion}

The highest ranked response categories were consistent amongst the types of institutions, but showed statistically significant differences in the frequency of responses. Two of the highest ranked responses, math/science and problem solving, occurred significantly more frequently at the medium private research university and significantly less frequently at the large state research university. Conversely, another top ranked response, innovation/creative/design, was mentioned significantly more frequently at the large state research university and significantly less frequently at the medium private research university. 
This difference in understanding of what engineering involves is also seen in the responses themselves. At the large state research university, statements such as "I like the design process" occurred frequently. One student even said that they did "not like to build things," but "likes to design" and this was why they chose engineering. This is in contrast to the medium-sized private university where the reasons for studying engineering were based largely on the fact that it is "heavily based on mathematics and physics [science]" and that engineers "apply math and science to the real world." At the small regional liberal arts college, some of these themes were seen, but more students (compared to the other schools) admitted that they were "not sure what engineering is about."Nothing definitive can be said as to why there are these differences in understanding about the nature of engineering at the different institutions based on this study, but might be due to the message being given to the students during recruitment to the respective programs. This might be an area of future research or this finding may at least help direct future recruitment efforts.

Another overall top ranked response, making a better world, was statistically less popular at the small private liberal arts college and more popular at the medium private university. Other overall popular responses, including how things work and building things, were consistent across the institutions.

The small private liberal arts college showed fewer statistically significant results, likely because there were fewer students (49 compared to 166 and 163 at the other institutions) and so comparisons involving that institution were not as statistically powerful.

The bottom ranked responses were also consistent at all institutions, but students at the large state university had statistically fewer responses in the categories of engineering being a good career, a broad field, having previous experience, and having a family member in engineering. Conversely, the medium private university had more respondents in the categories of having previous experience, a family member in engineering, and engineering being a broad field. It may be that students at the medium, private university are more socio-economically advantaged to have prior engineering experience and a family member in engineering. It is possible that those two categories are correlated as well, as engineering family members might encourage or seek out engineering experiences for high school children. Furthermore, the question was not explicitly asked if the students had a family member in engineering; thus, the information may have been volunteered by some students and not others. This may mean that this category in particular is biased low.

With regard to gender, statistical results could not be calculated for the small private liberal arts college due to the limited number of female students ( 3 out of 49). However, for the other two institutions statistically significant differences between genders were obtained. At the medium private university, males cited build things, how things work, innovative/creative/design more frequently than females, and females cited better world more frequently. This is consistent with findings in literature and with the overall results from this study. At the large public research university, females cited math/science and specific interests more frequently than males. These are consistent with the overall findings from this study; however, this differs from the findings of Seymour and Hewitt 
who found males citing math/science more frequently than females ${ }^{15}$. This may be due to the general infrequency of math and science being cited in this study at this institution. Males were found to cite broad more frequently than females at this institution, which is actually exactly opposite of the statistically significant result from the overall data (and at the medium private research university, although not statistically significant). It is also important to note that the trends between institutions are the same in most of the categories, even if they are not statistically significant at both institutions (the exceptions being in the categories of broad, family, and preparation for another career, with only broad being statistically significant).

It is also likely that the influence of gender may have confounded some of the institutional differences. As prior studies have reported, female students tend to cite making the world better more often, while male students tend to cite math/science and building things. It is therefore not surprising that at the small, private, regional liberal arts college, which is almost entirely male, math/science and building things were amongst the highest ranked, while making a better world occurred statistically significantly less frequently. Anecdotally, two of the three females did mention making the world better in their responses.Conversely, at the medium private institution, which had the highest percentage of females ( $31 \%$ vs $14 \%$ or $6 \%$ ), the better world response was one of the most-frequently cited.

There are limitations of this study. Using the open responses allows for some ambiguity in coding the results, and confounds some categories. The most striking of these was the students confounding the concepts of design, innovation, creativity, and building. Statements such as "I like to build and create things," or "I want to make [things] more efficient [or work better]" were made frequently by students, but especially at the large state research institution. There was some ambiguity on how exactly to code these types of general statements. To mitigate this limitation, two researchers coded the data independently and came to a consensus. Another limitation is that since this study was implemented at three different institutions, the orientation to engineering prior to giving the question may have been different, and may have influenced the results. All of the prompts were given during the first class or first assignment; however, any orientation events may have included a certain marketed perception of engineering that the students were exposed to in the days prior to starting class.

The strengths of this study are many. The study includes almost 400 first-year students at three different institutional types, allowing for statistically powerful comparisons rather than anecdotal evidence with small numbers. The study also combinesquantitative and qualitative methods in conjunction to strengthen the findings. Furthermore, this study represents a follow-up to a prior study, building a comprehensive picture of first-year motivations.

To continue building this comprehensive picture of first-year engineering students' motivations, work is underway to use these free responses to design a survey instrument to probe students further. These specific questions can use students' own words to elucidate the categories and ask students to rank the most important to them. Furthermore, specific questions such as "Do you have a family member that is an 
engineer?" and "Do you have previous experience in engineering?" will make sure none of the information is missed if not freely volunteered.

Finally, data is being collected on the persistence of these first-year students after the first and second semesters to determine if early student persistence is related to student motivation to enter engineering, and if this differs at different institutional types. This information could be used to screen students applying to programs, and to recruit students by marketing engineering in a way that interests students who will be successful.

\section{Summary}

A study was done comparing first-year student responses to the prompt, "Engineering is a very broad field of study. What is it about engineering that interests you?" at three institutions of different sizes and Carnegie Classifications. Statistically significant differences were observed between the institutions studied. The most notable difference was that the most cited reason at the large state university was innovative/creative/design, while math/science was the most frequently cited at the other institutions (where as it was not even in the top 5 reasons at the large state university).

These differences can be attributed, at least in part, to what the students at the different institutions believe engineers do. Other reasons for the differences might be differences in the socio-economic status of the student populations, differences in the messages the students hear during orientation or recruitment activities, and the gender distributions at the different schools. These are just conjectures, however, and further study needs to be done to discover the origin of these motivations.

This study provides important information about student motivations at different institutions. This information can be used to guide future research efforts to better understand why students choose to study engineering as well as aid in the development of curriculum and recruitment activities targeted toward the interests of the students in the hopes of increasing retention and enrollment in engineering programs.

\section{References:}

1. Astin, A. (1993). What Matters in College? ( $1^{\text {st }}$ ed.). San Francisco: Jossey-Bass Publishers.

2. Augustine, N. (2005). Rising Above the gathering Storm: Engineering and Employing America for a Brighter Future.

3. Besterfield-Sacre, M., Moreno, M., Shuman, L. J., Atman, C. J. (2001). Gender and Ethnicity Differences in Freshman Engineering Student Attitudes: A CrossInstitutional Study. Journal of Engineering Education, 90(4), 477-489.

4. Davey, F. H. (2001). The Relationship Between Engineering and Young Women's Occupational Priorities. Canadian Journal of Counseling, 35(3), 221.

5. Dick, T., \& Rallis, S. (1991). Factors and Influences on High School Students' Career Choices. Journal for Research in Mathematics Education, 22(4), 281-292. 
6. Duderstadt, J. J. (2007). Engineering for a Changing World. Ann Arbor, MI: University of Michigan.

7. Eris, O., Chachra, D., Chen, H., Rosca, C., Ludlow, L., Sheppard, S., et al. (2007). A Preliminary Analysis of correlations of Engineering Persistence: Results from a Longitudinal Study. Paper presented at the American Society for Engineering Education.

8. Lord, S., Cashman, E., Eschenbach, E., Waller, A. (2006). Feminism and Engineering. ASEE/IEEE Frontiers in Education Conference (F4H-14)

9. McMillan, J., \& Schumacher, S. (2006). Research in Education: Evidence-Based Inquiry ( $6^{\text {th }}$ ed.): Pearson Education.

10. Meyers, K., \& Mertz, B. (2011). A Large Scale Analysis of First-Year Engineering Student Essays on Engineering Interests. Paper presented at the American Society for Engineering Education.

11. NSF (2010). National Science Foundation: Bachelor's Degrees by field and sex 20002008 Retrieved 01/08/2012, 2012, from www.nsf.gov/statistics/wmpd/pdf/tab5-2.pdf.

12. Pascarella, E. T., Cruce, T., Umbach, P. D., Wolniak, G. C., Kuh, G. D., Carini, R. M., et al. (2006). Institutional Selectivity and Good Practices in Undergraduate Education: How Strong is the Link? Journal of Higher Education, 77(2), 251-285.

13. Patton, M. (2002). Qualitative Research \& Evaluation Methods ( ${ }^{\text {rd }}$ ed.). Thousand Oaks, CA: Sage Publications.

14. Seidman, A. (2005). College Student Retention: Formula for Student Success. American Council on education and Praeger Publishers.

15. Seymour, E., \& Hewitt, N. (1997). Talking About Leaving: Why Undergraduates Leave the Sciences. Bolder, Co.: WestviewPress.

16. Zhang, G., Anderson, T. J., Ohland, M. W., Thorndyke, B. R. (2004). Identifying Factors Influencing Engineering Student Graduation: A Longitudinal and CrossInstitutional Study. Journal of Engineering Education, 93(4), 313-320.

\section{Appendix}

Table 5: Comprehensive statistical data including 95\% Confidence Interval and p-value

\begin{tabular}{|c|c|c|c|c|}
\hline & Overall & $\begin{array}{c}\text { Medium Private } \\
\text { Research } \\
\text { University }\end{array}$ & $\begin{array}{c}\text { Large State } \\
\text { Research } \\
\text { University }\end{array}$ & $\begin{array}{c}\text { Small Private } \\
\text { Liberal Arts } \\
\text { College }\end{array}$ \\
\hline Math/Science & $\begin{array}{c}\mathbf{0 . 4 0 7} \\
95 \% \text { CI: } 0.358 \text { to } 0.457\end{array}$ & $\begin{array}{c}\mathbf{0 . 6 1 3} \\
0.538 \text { to } 0.689 \\
\text { p-value }<0.001\end{array}$ & $\begin{array}{c}\mathbf{0 . 1 6 9} \\
0.111 \text { to } 0.226 \\
\text { p-value }<0.001\end{array}$ & $\begin{array}{c}\mathbf{0 . 5 3 1} \\
0.389 \text { to } 0.672 \\
\text { p-value }=0.112\end{array}$ \\
\hline $\begin{array}{l}\text { Innovative/ } \\
\text { Create/Design }\end{array}$ & $\begin{array}{c}\mathbf{0 . 3 7 0} \\
95 \% \text { CI: } 0.321 \text { to } 0.419\end{array}$ & $\begin{array}{c}\mathbf{0 . 2 5 8} \\
0.190 \text { to } 0.325 \\
\text { p-value }=0.008\end{array}$ & $\begin{array}{c}\mathbf{0 . 4 8 2} \\
0.406 \text { to } 0.558 \\
\text { p-value }=0.016\end{array}$ & $\begin{array}{c}\mathbf{0 . 3 6 7} \\
0.231 \text { to } 0.504 \\
\text { p-value }=0.967\end{array}$ \\
\hline $\begin{array}{l}\text { Problem } \\
\text { Solving }\end{array}$ & $\begin{array}{c}\mathbf{0 . 2 7 5} \\
95 \% \text { CI: } 0.230 \text { to } 0.321\end{array}$ & $\begin{array}{c}\mathbf{0 . 3 6 8} \\
0.294 \text { to } 0.443 \\
\text { p-value }=0.037\end{array}$ & $\begin{array}{c}\mathbf{0 . 2 0 5} \\
0.143 \text { to } 0.266 \\
p=\text { value }=0.072\end{array}$ & $\begin{array}{c}\mathbf{0 . 2 0 4} \\
0.090 \text { to } 0.318 \\
\text { p-value }=0.260\end{array}$ \\
\hline Better World & $\begin{array}{c}\mathbf{0 . 2 4 3} \\
95 \% \text { CI: } 0.200 \text { to } 0.287\end{array}$ & $\begin{array}{c}\mathbf{0 . 3 2 5} \\
0.253 \text { to } 0.400 \\
\text { p-value }=0.058\end{array}$ & $\begin{array}{c}\mathbf{0 . 2 0 5} \\
0.143 \text { to } 0.266 \\
\text { p-value }=0.326\end{array}$ & $\begin{array}{c}\mathbf{0 . 1 0 2} \\
0.016 \text { to } 0.188 \\
\text { p-value }=0.005\end{array}$ \\
\hline Build Things & $\begin{array}{c}\mathbf{0 . 2 4 3} \\
95 \% \text { CI: } 0.200 \text { to } 0.287\end{array}$ & $\begin{array}{c}\mathbf{0 . 2 3 3} \\
0.168 \text { to } 0.298 \\
\text { p-value }=0.797\end{array}$ & $\begin{array}{c}\mathbf{0 . 2 2 9} \\
0.165 \text { to } 0.293 \\
\text { p-value }=0.714\end{array}$ & $\begin{array}{c}\mathbf{0 . 3 2 7} \\
0.194 \text { to } 0.459 \\
\text { p-value }=0.247\end{array}$ \\
\hline
\end{tabular}




\begin{tabular}{|c|c|c|c|c|}
\hline $\begin{array}{l}\text { Specific } \\
\text { Interest }\end{array}$ & $\begin{array}{c}\mathbf{0 . 2 1 2} \\
95 \% \text { CI: } 0.170 \text { to } 0.253\end{array}$ & $\begin{array}{c}\mathbf{0 . 2 3 3} \\
0.168 \text { to } 0.298 \\
\text { P-value }=0.585\end{array}$ & $\begin{array}{c}\mathbf{0 . 2 1 7} \\
0.154 \text { to } 0.280 \\
\text { p-value }=0.892\end{array}$ & $\begin{array}{c}\mathbf{0 . 1 2 2} \\
0.030 \text { to } 0.215 \\
\text { p-value }=0.089\end{array}$ \\
\hline $\begin{array}{l}\text { How Things } \\
\text { Work }\end{array}$ & $\begin{array}{c}\mathbf{0 . 2 0 4} \\
95 \% \text { CI: } 0.163 \text { to } 0.244\end{array}$ & $\begin{array}{c}\mathbf{0 . 1 5 3} \\
0.098 \text { to } 0.209 \\
\text { p-value }=0.152\end{array}$ & $\begin{array}{c}\mathbf{0 . 2 4 7} \\
0.181 \text { to } 0.313 \\
\text { p-value }=0.274\end{array}$ & $\begin{array}{c}\mathbf{0 . 2 2 4} \\
0.106 \text { to } 0.343 \\
\text { p-value }=0.745\end{array}$ \\
\hline $\begin{array}{l}\text { Practicality/ } \\
\text { Real World }\end{array}$ & $\begin{array}{c}\mathbf{0 . 1 9 3} \\
95 \% \text { CI: } 0.153 \text { to } 0.233\end{array}$ & $\begin{array}{c}\mathbf{0 . 2 3 9} \\
0.173 \text { to } 0.305 \\
\text { p-value }=0.240\end{array}$ & $\begin{array}{c}\mathbf{0 . 1 3 3} \\
0.081 \text { to } 0.184 \\
\text { p-value }=0.070\end{array}$ & $\begin{array}{c}\mathbf{0 . 2 4 5} \\
0.123 \text { to } 0.367 \\
\mathrm{p} \text {-value }=0.431\end{array}$ \\
\hline Good Career & $\begin{array}{c}\mathbf{0 . 0 9 3} \\
95 \% \text { CI: } 0.063 \text { to } 0.122\end{array}$ & $\begin{array}{c}\mathbf{0 . 1 3 5} \\
0.082 \text { to } 0.188 \\
\text { p-value }=0.169\end{array}$ & $\begin{array}{c}\mathbf{0 . 0 4 8} \\
0.016 \text { to } 0.081 \\
\text { p-value }=0.048\end{array}$ & $\begin{array}{c}\mathbf{0 . 1 0 2} \\
0.016 \text { to } 0.188 \\
\text { p-value }=0.838\end{array}$ \\
\hline Broad & $\begin{array}{c}\mathbf{0 . 0 8 5} \\
95 \% \text { CI: } 0.057 \text { to } 0.113\end{array}$ & $\begin{array}{c}\mathbf{0 . 1 6 0} \\
0.103 \text { to } 0.216 \\
\text { p-value }=0.021\end{array}$ & $\begin{array}{c}\mathbf{0 . 0 1 8} \\
-0.002 \text { to } 0.038 \\
\text { p-value }<0.001\end{array}$ & $\begin{array}{c}\mathbf{0 . 0 6 1} \\
-0.007 \text { to } 0.129 \\
\text { p-value }=0.534\end{array}$ \\
\hline $\begin{array}{l}\text { Previous } \\
\text { Experience }\end{array}$ & 95\% CI: 0.052 to 0.107 & $\begin{array}{c}\mathbf{0 . 1 5 3} \\
0.098 \text { to } 0.209 \\
\text { p-value }=0.020\end{array}$ & $\begin{array}{c}\mathbf{0 . 0 1 8} \\
-0.002 \text { to } 0.038 \\
\text { p-value }<0.001\end{array}$ & $\begin{array}{c}\mathbf{0 . 0 4 1} \\
-0.015 \text { to } 0.097 \\
p \text {-value }=0.229\end{array}$ \\
\hline Family & $\begin{array}{c}\mathbf{0 . 0 7 4} \\
95 \% \text { CI: } 0.048 \text { to } 0.101\end{array}$ & $\begin{array}{c}\mathbf{0 . 1 4 1} \\
0.087 \text { to } 0.195 \\
\text { p-value }=0.029\end{array}$ & $\begin{array}{c}\mathbf{0 . 0 1 2} \\
-0.005 \text { to } 0.029 \\
\text { p-value }<0.001\end{array}$ & $\begin{array}{c}\mathbf{0 . 0 6 1} \\
-0.007 \text { to } 0.129 \\
\text { p-value }=0.731\end{array}$ \\
\hline Group Work & $\begin{array}{c}\mathbf{0 . 0 3 2} \\
95 \% \text { CI: } 0.014 \text { to } 0.049\end{array}$ & $\begin{array}{c}0.025 \\
0.001 \text { to } 0.048 \\
\text { p-value }=0634\end{array}$ & $\begin{array}{c}\mathbf{0 . 0 4 2} \\
0.012 \text { to } 0.073 \\
\text { p-value }=0.564\end{array}$ & $\begin{array}{c}\mathbf{0 . 0 2 0} \\
-0.020 \text { to } 0.060 \\
\text { p-value }=0.613\end{array}$ \\
\hline $\begin{array}{l}\text { Prep for Other } \\
\text { Career }\end{array}$ & $\begin{array}{c}\mathbf{0 . 0 2 6} \\
95 \% \text { CI: } 0.010 \text { to } 0.042\end{array}$ & $\begin{array}{c}\mathbf{0 . 0 4 9} \\
0.016 \text { to } 0.082 \\
\text { p-value }=0.232\end{array}$ & $\begin{array}{c}\mathbf{0 . 0 1 2} \\
-0.04 \text { to } 0.029 \\
\text { p-value }=0.225\end{array}$ & $\begin{array}{c}\mathbf{0 . 0 0 0} \\
-- \\
\text { p-value }=0.001\end{array}$ \\
\hline
\end{tabular}

